\title{
SOME AUSTRALIAN BRACHIOPODS
}

\author{
By F. Blochman,
}

Professor of Zoology in the University of Tübingen

(Communicated by W. L. May)

Plates x.-xii.*

Read 8th September, 1913.

The following Paper was sent by Professor Blochmann to Dr. J. C. Verco, of Adelaide, who translated it, and sent it to Mr. W. I. May, by whom it is communicated to the Society.

The specimens of Terebratula (Liothyrina) fulra and Argyrotheca (Cistella) Mayi, described below, were taken by Mr. May on 26th March, 1910, during a dredging trip of the Tasmanian Field Naturalists' Club. ('see Tasmanian Field Naturalists' Club Report on Easter C'emp. (Jut, 1910, to Cole's Bay, Freycinet Peninsula, East Coast, T'asmania.)

Dr. Verco, of Adelaide, who presented to me some time ago a fine collection of Australian Brachiopods, sent to me at the beginning of this year a number af Brachiopods, which were collected by Mr. W. L. May, of Forest Hill, Sandford, Tasmania, on the Tasmanian Coast. This material, for which I on this occasion heartily thank both these gentlemen, contains, besides two new species, complete and well preserved examples of the species Tereiratula (Liothyrina) fulva, created by me in 1908, which was known hitherto only by one single empty shell, obtained by the Challenger expedition from Twofold Bay, on the South-East Coast of Australia. By means of the examples now lying before me, the specific independence of this Australian Terebratula, created by me, is quite certainly established. I give now a complete description of this species, and add thereto descriptions of the other two new species.

\section{Terebratula (Liothyrina) fulva, Blochmann.}

$$
\text { (Plates x., xii., fig. 1-6, 12a, 12b.) }
$$

(T. uva, Broderip p.p. Davidson, Chall. Rep. P. 31, Pl. ii., fig. 3, 3a, 3b. Liothyris uva, Broderip, p.p. Davidson, Rec Brachiopoda, p. $10, \mathrm{Pl}$. 11., fig. 7. Liothyrina fulva, Blochmann, 1906, Zool. Anz. xxx., p. 698, and 1908 Zeitschr. f. Wiss. Zool. Bd. xc., p. 617, Pl. 38, fig. 22a, 22b, Pl. 39, fig. 26.)

*The plates are from photographic prints supplied by the author. The prints were damaged before they reached the Society, and in consequence it has not been possible to produce clear plates. 
1913.

In outline, slender to broad pearshaped, broadest in the middle. Beak short, with slightly pronounced edges, moderately sharply curved dorsalwards. Deltidial plates touching each other. Lateral edges in the neighbourhood of the hinge with a weak convexity directed dorsalwards, otherwise straight. Ventral valve, somewhat deeper than the dorsal; both equally arched. Growth-strix invalid. Colour, pure white, very transparent. The Brachial apparatus of both the new exmples (fig. 1, 5, and 6) corresponds essentially with the characters of the Challenger example. In the shell illustrated in fig. 6 , the bridge of the Brachial apparatus is somewhat more strongly bent ventralwards, and at the front edge somewhat more excavated than in the Challenger specimen. (The peculiar yellowish colour of the Challenger example has arisen, as the present fresh shells show, through some circumstance after death of the animal.) The number of pores of the one example (fig. 1 and 2) amount to 136, of the other (fig. 3 and 4) to 104, in the Challenger example to 120-130. The inner surface of the shells shows the presence of mosaic, which is found in most of the Liothyrina, as illustrated by me for L. vitrere (1908, Pi. 37, fig. 15). T. fulva has wo cirri bases, and in both rows of cirri slender spicula. (As the examples at my disposal are dry, the spicula of the arms are partly broken, and also somewhat out of position. I am, therefore, unable to give a good illustration.) The headplates on the dorsal side of the sidearms in the back half are stout. and plentifully branched, and fairly thickly thorned, but in the front half small, with few slender extensions, sparingly thorned. In the body-wall, particularly in the dorsal part, are found stout strongly thorned plates, differing somewhat in formation, in the two examined examples (fig. 12 a and b). The mantle contains only in the course of the sinus, and nearly to the extreme ends of the sinus-branches, simple fine spicula; on this account the course of the sinus, in dry examples, stands out very distinctly.

Dimensions of the two illustrated examples in millimetres. Fig. 1 and 2 . Fig. 3 and 4.

$\begin{array}{lrrrrrrrr}\text { Leugth } & \ldots & \ldots & \ldots & 17 \cdot 0 & \ldots & \ldots & \ldots & 15 \cdot 0 \\ \text { Breadth } & \ldots & \ldots & \ldots & 11 \cdot 5 & \ldots & \ldots & \ldots & 12 \cdot 0 \\ \text { Thickness } & \ldots & \ldots & \ldots & 9 \cdot 0 & \ldots & \ldots & \ldots & 9 \cdot 0\end{array}$

Habitat, 3 miles east of Schouten Island, on the East Coast of Tasmania. Depth $73 \mathrm{~m}$. (40 fathoms). This 
locality is about $500 \mathrm{~km}$. distant from Twofold Bay, where the Challenger example comes from. It may consequently be assumed that this species extends to the South and the South-East Coast of Australia.

\section{Terebratella Mayi, n. sp. (Plate xi., fig. 7, 8, 9.)}

A small kind, nearly as long as broad. Greatest breadth in the middle. In the front half of the dorsal valve a faint median sinus. Growth-striæ distinctly to strongly developed. Ribbing slightly pronounced, and quite absent on the older parts of the shell. Beak, in young examples with faintly, in older ones distinctly, developed edges. Deltidial plates in the illustrated example touching each other. In the largest example (from which fig. 9 is derived) they are separated, which possibly results from absorption in the dead shell. The Brachial apparatus is not completely preserved in any of the examples (only empty shells are displayed), yet they show, as we can conclude from the remuants, the characters of Terebratella dorsata (fig. 9). There is a high median-septum developed, which is connected at the back with the hingeplate. At the point where the connection of the descending limb reaches the septum, this subsides, curving gently towards the front, to end rather far in front of the middle of the valve. The described general characters of the shell would, apart from its small size, hardly suffice to permit a definite distinction of the frresent species from $T$. dorsata. Nevertheless, the characters of the pores provide clear distinction.

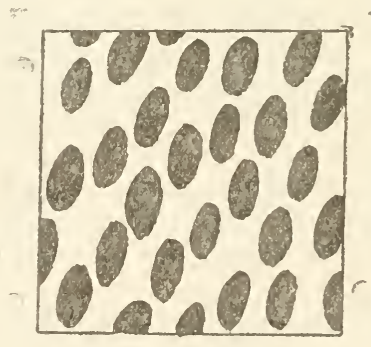

Terebratella mayi-outer surface of the midale part of the dorsal valve (106 $\times, 9$ sq. mm.)

The number of pores in the sq. mm. amount to 300 (in T. dorsata, 180-212). T'he iuner diameter of the sheli tubes is $15 \mu$, and the outer oval openiug of the same ineasures $60 / 35 \mu$. 


\section{Dimensions in millimetres.}

Largest example. Example figs. 8,9.

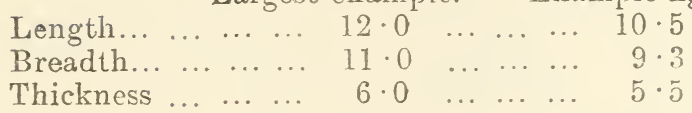

Habitat, off Cape Pillar, Tasmania, at a depth of $180 \mathrm{~m}$. 100 fathoms).

3. ArgyrothecA (C'istelia) DIAr, D. sl. (Platexi., fig. 10, 11.)

Outline, nearly rectangular, broadened more or less toards the front, so that the outline is nearly triangular. The front edge is slightly indented. Both valves have a slight median-sinus. Hinge line nearly straight. Dorsalvalve is perforated. Beak very short and broad; beak edges sharp. Adjoining these towards the middle is a flat area. Stem hole very wide, bordered on the side by very narrow deltidial plates, and in front by the edge of the hinge. The ventral valve is quite flat, the dorsal a good deal arched. In the ventral valve a moderately high median-septum reaching beyond the middle. In the dorsal valve a median furrow, bordered on the sides by a low ledge, sinks down from the hinge border nearly to the middle of the valve. Where the furrow ends a high, thick, median-septum arises, reaching quite to the edge of the valve, and the base resting upon the valve is about couble the length of the free edge. The crura are short and broad, with pronounced crural prolongations. The descending limbs attach themselves, after a short course, on the inner surface of the valve, and disappear. On each side of the lower part of the side surfaces of the septum arises a small band descending to the surface of the valve, a remnint of the arm-lcop. Number of pores in the sq. $\mathrm{mm}$. about 200. Diameter of the outer opening of the shelliutue, $15.17 \mu$.

\section{Dimensioms in millimetres.}

$\begin{array}{llllllllll}\text { Length } & \ldots & \ldots & \ldots & \ldots & \ldots & \ldots & \ldots & \ldots & 2 \cdot 5 \\ \text { Breadth } \ldots & \ldots & \ldots & \ldots & \ldots & \ldots & \ldots & \ldots & 2 \cdot 0 \\ \text { Thickness } & \ldots & \ldots & \ldots & \ldots & \ldots & \ldots & \ldots & & 1 \cdot 0\end{array}$

Habitat, about $18 \mathrm{~km}$. (10 miles) east of Schouten Island, East Coast of Tasmania. Depth. $145 \mathrm{~m}$. (80 fathoms). Only empty shells were obtained. This species is certainly distinct from the Aryyrothecr. (Cistella) australis (Trans. Por. Soc. S. Aus., Vol. xxxiv., 1910, P]. xxvii, figs. 10-12), formerly described by me, also from all other known species. 


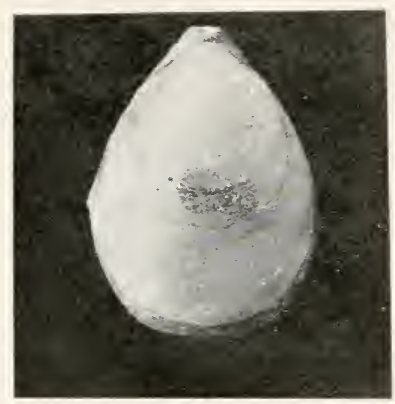

Fig. $1(2 \times)$

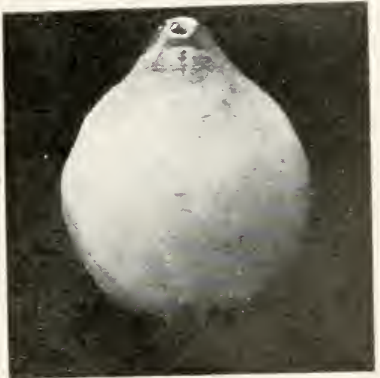

Fig. $3(2 \times)$

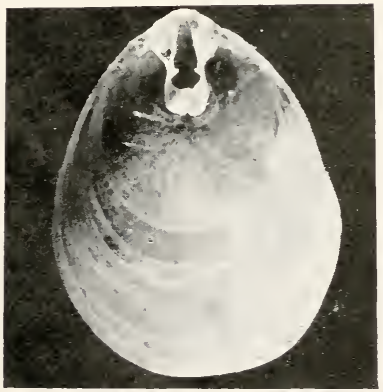

Fig. $5(2.5 \times)$

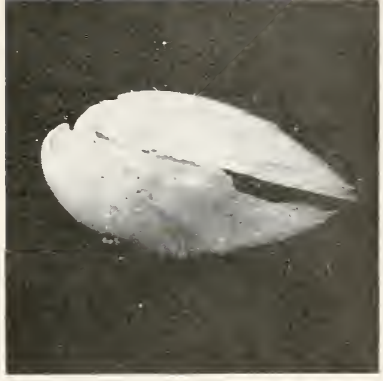

Fig. $2(2 \times)$

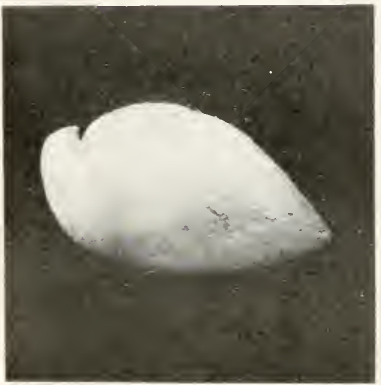

Fig. $4(2 \times)$

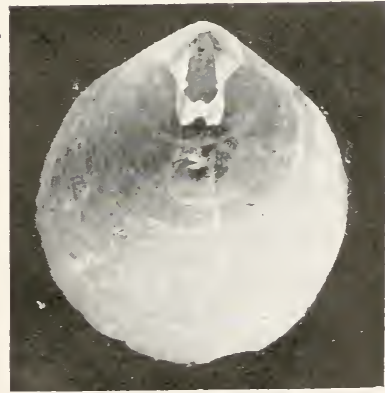

Fig. $6(2.5 x)$

Terebratula 'Liothyrina' fulva, Blochmann.

1, 2, Dorsal and side view of a more slender example.

3,4 , The same from a broader example.

5 , Brachial apparatus of example, fig. 1.

$6, \quad,, \quad$,, ," 3. 


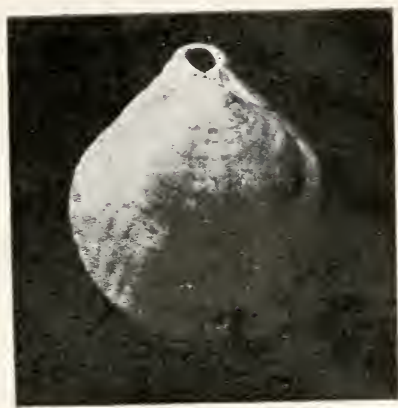

Fig. $7(3 \times)$

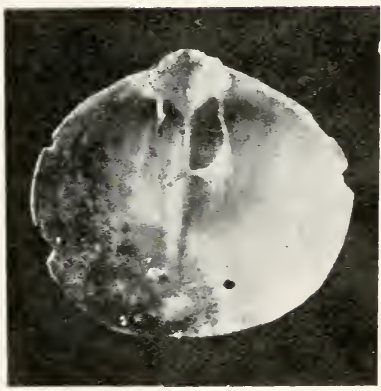

Fig. $9(3 \times)$

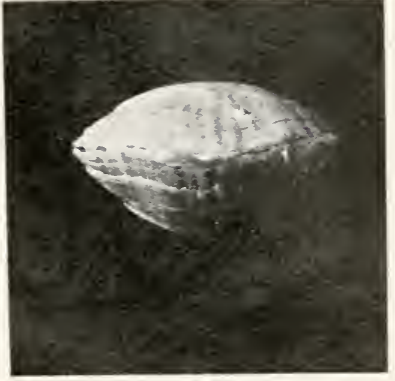

Fig. $8(3 \times)$

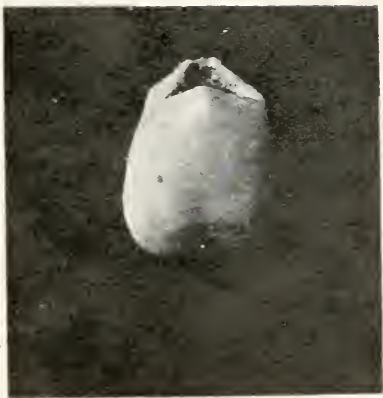

Fig. $10(8 x)$

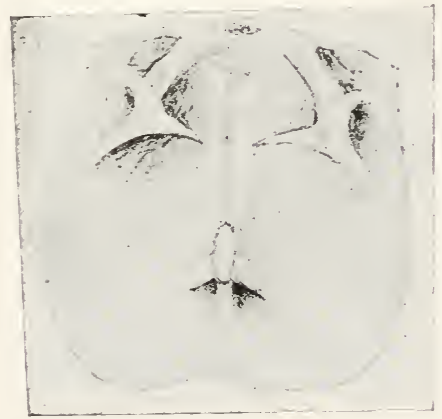

Fig. $11(16 \times)$

7-9. Terebratella mayi, n. sp.

7, Dorsal view.

8, Front view.

9, Brachial apparatus of a larger example.

10, 11. Arajrotheca mayi, n. sp.

10, Dorsal view.

11. Inner view of dorsal valve. 


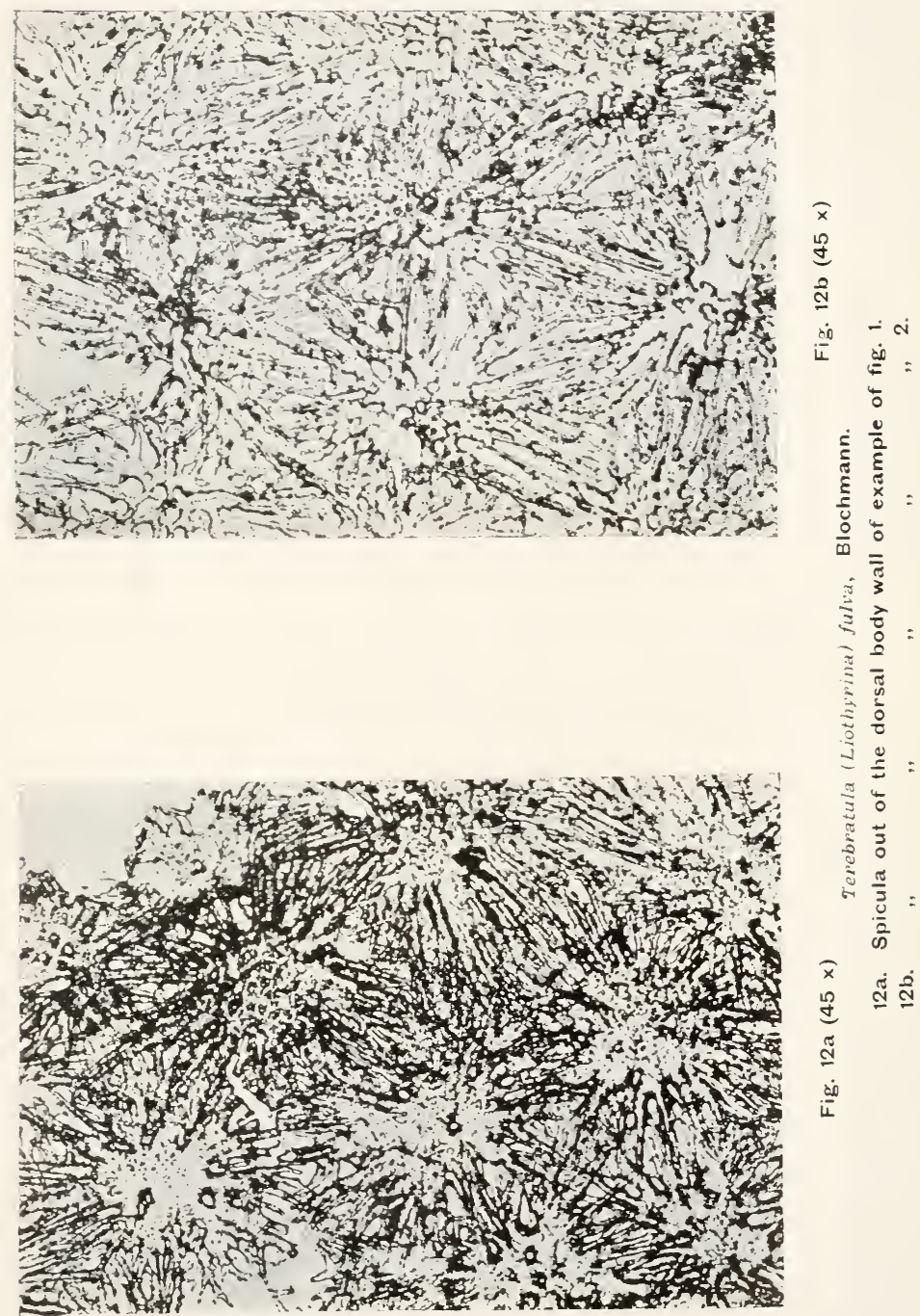

